\title{
Effectiveness of combinations of raft foundation with aprons as a protection measure against bridge pier scour
}

\author{
B A VIJAYASREE, T I ELDHO*, B S MAZUMDER and B V S VISWANADHAM \\ Department of Civil Engineering, Indian Institute of Technology Bombay, Mumbai 400076, India \\ e-mail:vijisunoj@gmail.com; eldho@civil.iitb.ac.in; bsmazumder@gmail.com; viswam@civil.iitb.ac.in
}

MS received 4 August 2016; revised 4 June 2017; accepted 3 August 2017; published online 10 March 2018

\begin{abstract}
Scour around bridge pier is the main reason for the failure of bridges. The local scour around the pier causes exposure of the foundation and may lead to undermining of the structure. Different types of protection measures such as the provision of raft, apron, sheet piles, etc. can be used as scour protection measures. One of the possible effective bridge scour protection measures is to provide a raft foundation with cutoff walls and provision of flexible stone aprons towards upstream $(\mathrm{u} / \mathrm{s})$ and downstream $(\mathrm{d} / \mathrm{s})$ sides of the pier. In this study, the effectiveness of various bridge pier scour protection measures using raft and aprons is investigated through hydraulic model studies in the laboratory. The results are compared for various cases, such as a simple pier, pier with raft and extended raft, pier resting on a raft with stone aprons at $\mathrm{u} / \mathrm{s}$ and $\mathrm{d} / \mathrm{s}$ of the raft and pier resting on an extended raft with stone aprons on $\mathrm{u} / \mathrm{s}$ and $\mathrm{d} / \mathrm{s}$ of it. The comparison of various cases showed that rigid raft with stone aprons on $\mathrm{u} / \mathrm{s}$ and $\mathrm{d} / \mathrm{s}$ and extended raft with apron are found to be more effective in reducing immediate scour beyond the rigid raft, thereby giving protection to the bridge piers.
\end{abstract}

Keywords. Scour; pier; raft foundation; stone aprons; scour protection; physical model study.

\section{Introduction}

When a bridge pier partially obstructs an alluvial stream, the flow pattern in the stream around the pier changes significantly because of the interaction between the pier and the stream flow. An adverse gradient in pressure is produced by the pier right at its upstream side. The flow undergoes a three-dimensional separation at the upstream of the pier. Due to this separation, shear stress distribution around the pier changes in a major way due to the formation of a horseshoe vortex, which results in the formation of a scour hole around the pier. Due to the formation of scour hole, the flow pattern and shear changes ([1-3] and others). In fact, the fluid flow directly affects the pier and the latter, as a back reaction, modifies flow field around the pier, and hence the scour at the bed. River bridges crossing alluvial beds are highly susceptible to scouring at piers and at abutments due to obstruction of flow. Therefore, the bridge piers should be designed to resist severe scouring action due to the flow and adequate scour protection measures should be adopted.

Several research works were undertaken across different parts of the world to determine suitable scour protection systems. The major protective measure techniques employed for preventing or minimising local scour at bridge piers can be classified into three categories: (1) bed

*For correspondence armouring protective measures; (2) flow-altering protective measures and (3) a combination of these two measures. Riprap, gabion mattresses, grout-filled bags, geobags, etc. are some examples of bed armouring scour protection ([4-7] etc.). Tetrahedral frames, ring columns, collars, sheath, etc. are some examples of flow-altering protective measures [8-13]. Effect of combination of different flow-altering measures, like submerged vanes and bed sill, slot and sacrificial piles, collar and sacrificial piles, slot and collar, and bed sill and collar were also studied [14]. Rafts with a flexible apron, riprap and collar are a few examples of combination of bed armouring and flow-altering counter-measures (IRC 78-2000 [15]; IRC 89-1997 [16-18]).

When a wide slot of one-fourth the diameter was placed near the water surface or the bed level, the scour depth reduced by almost $20 \%[19,20]$. If the slot was as wide as one-half the diameter, placed near the water surface, the reduction in clear-water scour depth was by nearly $30 \%$ $[19,20]$. When a slot placed near the bed was in combination with a collar, it was observed that the combination eliminated the scouring completely. A kind of riprap failure, identified under live-bed conditions, is the bed-form destabilisation of the riprap layer due to the migration of ripples and dunes with fluctuations of bed level [21]. Therefore, in order to manage the heavy scour around the piers, the rigid raft system may be used as one of the protection measures for the bridge piers. 
Several cases were studied to determine the scour depth in boulder bed rivers under high stream velocities by Dey and Sen [22]. They attempted to estimate scour depth for general beds, within channel contractions and at bridge piers in boulder bed rivers by adopting physical modelling techniques. They verified the effects of various parameters on scour depth. They also suggested scour protection measures like collars and stone pitching. Kothyari [23] provided details on various methods of estimating scour depth followed in India. Ugalmugale and Namjoshi [24] explained in detail the construction of raft foundation for bridges across perennial rivers. Borge and Jangde [25] suggested that a raft foundation can be used effectively on bridges across small and medium rivers.

\subsection{Raft system as a scour protection measure}

The foundation strata for bridge structures while executing bridge projects vary from exposed hard rock to pure sand for a considerable depth. If a good founding stratum is not available in a shallow depth, the construction of small bridges becomes uneconomical. For example, the majority of the rivers in Maharashtra have thick sandy beds, where raft foundation is a feasible solution [25]. Raft has been proved to be a good economical method for constructing bridge foundation. The adoption of cut-off along with an apron is found to be adequate to prevent scour. There is also a further scope of reduction of these provisions depending on depth, water velocity, type of bridge, i.e., submersible/high-level, etc. According to the Indian Road Congress (IRC) guidelines (IRC: 78-2000 [15]; IRC: 89-1997 [16]), to control the scour around bridge piers to be economical, the floor protection measure should be considered during the adoption of shallow foundations. The floor protection comprises a rigid raft with cut-off walls and a flexible apron mainly to check scour. The maximum velocity of the flow should be less than $2 \mathrm{~m} / \mathrm{s}$ and the intensity of discharge should be limited to $3 \mathrm{~m}^{3} / \mathrm{m}$. The rigid raft should be enclosed by cut-off walls to a minimum of $2 \mathrm{~m}$ on the upstream $(\mathrm{u} / \mathrm{s})$ side and $2.5 \mathrm{~m}$ on the downstream $(d / s)$ side. The rigid raft should be continued over the top width of cut-off walls. A 1-m thick flexible apron comprising loose stone boulders, weighing at least $40 \mathrm{~kg}$, should be provided beyond the cut-off walls at a minimum distance of 3 $\mathrm{m}$ on the upstream side and $6 \mathrm{~m}$ on the downstream side. Cement concrete blocks or wire crates filled with stones may also be used in place of boulders.

According to Ugalmugle and Namjoshi [24] and Borge and Jangde [25], raft foundation was found to be the most economical in the case of weak soils where an open foundation was not feasible. Raft foundations can be most effectively used on small streams and medium rivers. In Maharashtra, the major rivers, like Godavari and Waingangā, have been bridged with raft foundations including the stone aprons. The width of the raft was equal to the length of the pier. The length of apron towards upstream was considered as 1.5 times the depth of scour and downstream apron as twice the scour depth from the bed level. According to IRC 78-2000 [15] guidelines, the mean scour depth $\left(d_{m s}\right)$ below the highest flood level (HFL) for natural channels can be evaluated from the equation as

$$
d_{m s}=1.34 \sqrt[3]{\frac{D_{b}^{2}}{K_{s f}}}
$$

where $D_{b}$ is the design flow discharge per unit width of effective waterway and $K_{s f}$ is the silt factor for a representative sample of bed materials obtained up to the level of anticipated deepest scour. The silt factor $K_{s f}$ for a representative sample of bed materials is determined by the expression as $1.76 \sqrt{d_{m}}$, where $d_{m}$ is the weighted mean diameter in $\mathrm{mm}$. Raft foundations are also found to be equally good for submersible bridges [25]. This is typical for Maharashtra practice for constructing bridges. Table 1 provides the details of the few bridges constructed with raft foundation including stone apron at different parts of Maharashtra during past few decades. Here, the foundation system, which consists of raft with cut-off and with flexible aprons on the upstream and downstream, is found to be adequate to prevent scour [25].

In spite of the plenty of work done on local scour around bridge piers, a detailed literature review showed that very few investigations have been performed in Indian conditions to understand the physical nature of scour geometry around pier with raft foundations and flexible aprons, despite the fact that such a study in the laboratory has the potential to identify the effectiveness of scaled-down models of the pier resting on a raft with flexible aprons on both upstream and downstream of the pier. The reduction in scour depth using rafts with stone aprons is an important process to understand the effect of rafts and aprons in the scour. Now the question is whether the reduction of scour

Table 1. Summary of bridges constructed on raft foundation in Maharashtra.

\begin{tabular}{|c|c|c|c|c|}
\hline Name & Location & Length & $\begin{array}{c}\text { No. of } \\
\text { spans }\end{array}$ & Year \\
\hline Belwan Nalla & Solapur district & $132 \mathrm{~m}$ & 24 & 1983 \\
\hline Man river & Satara district & $56 \mathrm{~m}$ & 7 & 1974 \\
\hline Yerla river & Satara district & $42 \mathrm{~m}$ & 7 & 1981 \\
\hline $\begin{array}{l}\text { Khobragadi } \\
\text { river }\end{array}$ & $\begin{array}{c}\text { Gadchiroli } \\
\text { district }\end{array}$ & $\begin{array}{c}315.82 \\
\mathrm{~m}\end{array}$ & 42 & 1985 \\
\hline Perimili river & $\begin{array}{c}\text { Gadchiroli } \\
\text { district }\end{array}$ & $48 \mathrm{~m}$ & 12 & $\mathrm{n} / \mathrm{a}^{*}$ \\
\hline Talwada Nalla & $\begin{array}{c}\text { Gadchiroli } \\
\text { district }\end{array}$ & $13.5 \mathrm{~m}$ & 4 & $\mathrm{n} / \mathrm{a}$ \\
\hline $\begin{array}{l}\text { Vilochana } \\
\text { river }\end{array}$ & $\begin{array}{c}\text { Gadchiroli } \\
\text { district }\end{array}$ & $40.75 \mathrm{~m}$ & 8 & 1985 \\
\hline Purna river & $\begin{array}{r}\text { Amrawati } \\
\text { district }\end{array}$ & $\begin{array}{c}170.20 \\
\mathrm{~m}\end{array}$ & 22 & 1996 \\
\hline
\end{tabular}

*Year of construction "not available" 
depth depends only on the extension of raft in both upstream and downstream sides of the pier, or it depends on the raft with flexible aprons on both sides of the pier. Therefore, a detailed investigation is required to understand the basic hydrodynamic phenomena experimentally in a laboratory flume around a pier resting on a raft foundation with flexible aprons. The physical nature of protective measurable techniques to prevent or minimise the scour around bridge piers is still an open problem, which needs to be studied.

The objective of the present study is to effectively use the physical modelling technique to understand the scouring behaviour around a simple bridge pier resting on raft foundation and its variations with stone aprons on both sides. The study is carried out for identification of scour depth around the piers with raft foundations along with aprons, which might provide a clue for suggesting the model design with possibilities of protection against heavy scour. Here, in order to understand the scouring phenomena with various protection measures, following five cases are studied: (1) simple pier, (2) pier with raft foundations, (3) raft extended to both upstream $(\mathrm{u} / \mathrm{s})$ and downstream $(\mathrm{d} / \mathrm{s})$ by a distance equal to the width of pier, (4) raft with stone aprons up to a distance of $0.3 \mathrm{~m} \mathrm{u} / \mathrm{s}$ and $0.5 \mathrm{~m} \mathrm{~d} / \mathrm{s}$ and (5) raft extended to $\mathrm{u} / \mathrm{s}$ by a width of the pier and $\mathrm{d} / \mathrm{s}$ by three times of the pier width with stone aprons on both sides by a distance twice the pier width. The experiments were conducted for different flow depths and flow discharges.

\section{Experimental study}

Experiments were carried out in a horizontal masonry flume constructed at the Hydraulics Laboratory of Indian Institute of Technology (IIT), Bombay, India. The flume was $11 \mathrm{~m}$ long, $2 \mathrm{~m}$ wide and $1.3 \mathrm{~m}$ deep, having a plain cement concrete (PCC) floor. At a distance of $6 \mathrm{~m}$ from the upstream end of the flume, a Perspex window of length $3 \mathrm{~m}$ was provided, which facilitated the observation of scour and flow behaviour. The pier model was artificially made by steel and wood, and the raft was made of marine plywood sheets of $12 \mathrm{~mm}$ thickness, which acts as a rigid bed,
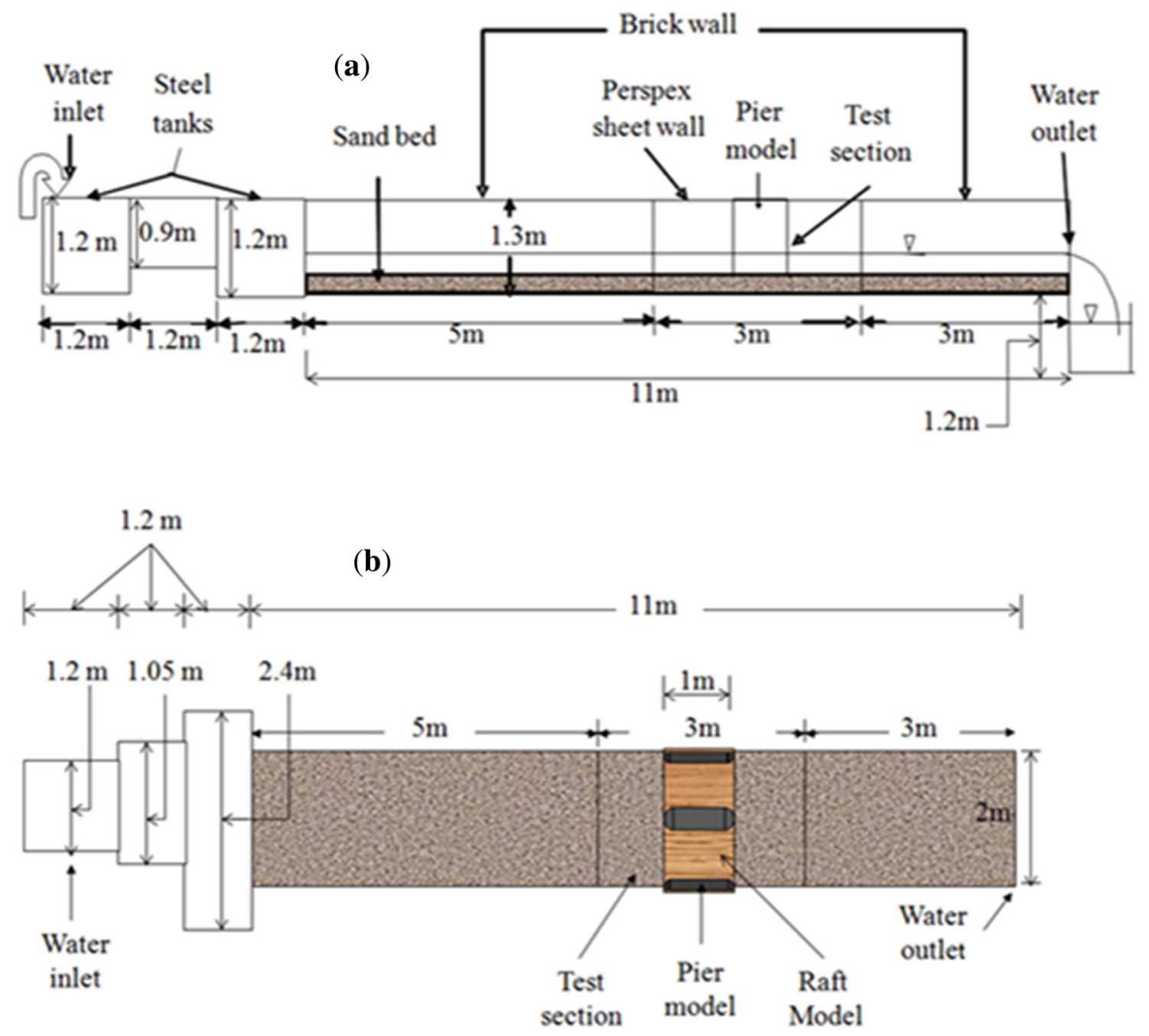

Figure 1. Schematic diagram of the experimental flume with sand bed: (a) side view; (b) plan view. 
very similar to a typical raft foundation. Stone aprons were provided in both upstream and downstream sides of the pier. The water was pumped from the sump into the inlet tank of the flume and re-circulated. Series of experiments were conducted for different combinations of scour protection measures.

In this study, a bridge with two spans was considered so that one central pier and two side piers were provided with a raft foundation, which extended to the entire width of the flume and was placed in the test section. Adequate arrangements were made to dissipate the energy during inletting of water. Water entered into the channel through a bell mouth arrangement. Wire mesh and pebbles were placed at the entry point of the flume to make sure that the flow of water was smooth and free of vortices.

Figure 1a and $b$ shows diagrams of the flume at the test section: (a) a schematic longitudinal section view with the sand bed and (b) a plan view with the pier model resting on the raft over the sand bed. The scale chosen was 1:10 based on Froude number similitude [26, 27]. Pier and raft models were placed at the centre of the test section as shown in figure $1 \mathrm{~b}$. The sediment bed material was river sand $\left(d_{50}=\right.$ $0.5 \mathrm{~mm}$, specific gravity $=2.93$ with $98.1 \%$ sand content). The sand grain-size distribution and the properties of the sand are, respectively, shown in figure 2 and table 2 . The sand used in the present study can be classified as SW according to Unified Soil Classification system (Head, [28]).

In order to identify the scour holes due to flow discharges around the pier with different raft foundations, experiments were conducted in the flume using five cases (described in the objective) presented in figure $3 \mathrm{a}-\mathrm{e}$. Here, the $x$-axis is considered as along the flow, $y$-axis as transverse to the
Table 2. Properties of soil used in the experimental study.

\begin{tabular}{lc}
\hline Soil property & Value \\
\hline Specific gravity & 2.93 \\
$\mathrm{~d}_{50}$ & $0.5 \mathrm{~mm}$ \\
$\%$ Gravel & 1.25 \\
$\%$ Sand & 98.1 \\
\% Silt & 0.65 \\
\% Clay & 0 \\
Coefficient of uniformity, $\mathrm{C}_{\mathrm{u}}$ & 2.72 \\
Coefficient of curvature, $\mathrm{C}_{\mathrm{c}}$ & 1.094 \\
Maximum void ratio, $\mathrm{e}_{\max }$ & 1.1 \\
Minimum void ratio, $\mathrm{e}_{\min }$ & 0.77 \\
Placement void ratio, $\mathrm{e}^{*}$ & 0.92 \\
Permeability at e $=0.92$ & $0.0004 \mathrm{~m} / \mathrm{s}$ \\
Soil classification $(\mathrm{USCS})$ & $\mathrm{SW}$ \\
\hline
\end{tabular}

*Void ratio of sand placed in the flume

flow and $z$-axis as normal to the flow. The flow discharge was measured using a Ultrasonic flow meter. All experiments were conducted for a range of flow discharges between 0.03 and $0.21 \mathrm{~m}^{3} / \mathrm{s}$, average velocities $0.14-0.50$ $\mathrm{m} / \mathrm{s}$ and the flow depth ranging from 0.11 to $0.214 \mathrm{~m}$. The highest possible discharge in the flume was $0.21 \mathrm{~m}^{3} / \mathrm{s}$. The flow velocity was measured using a Programmable Electromagnetic Liquid Velocity Meter from Delft Hydraulics at different sections. The flow depth was measured using a point gauge. The scour depth was recorded using a $2 \mathrm{D}$ bed profiler procured from HR Wallingford.

Initially, experiments were conducted using a simple pier (Case 1) of width $0.09 \mathrm{~m}$, length $1 \mathrm{~m}$ and span width $1 \mathrm{~m}$, as shown in figure 3a. After the desired discharge was obtained, a sufficient time of about $8 \mathrm{~h}$ was allowed for the

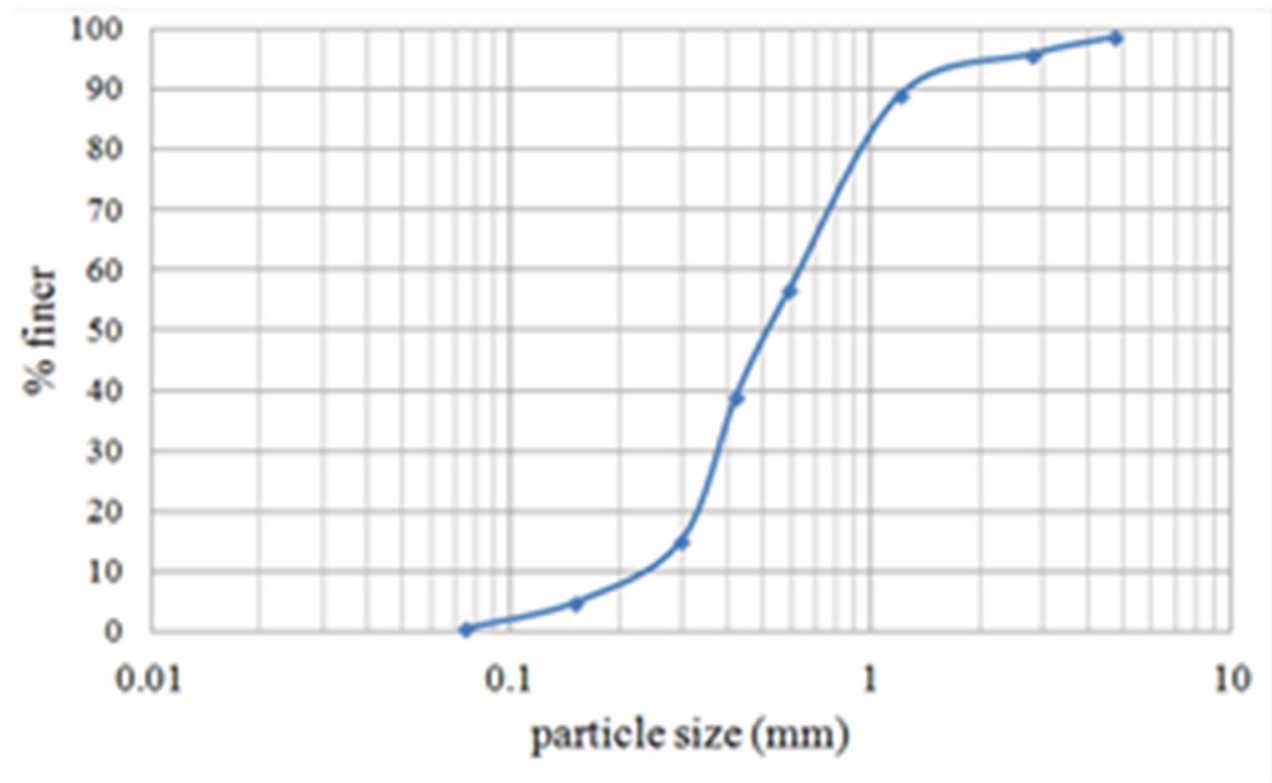

Figure 2. Grain size distribution of sand bed material. 


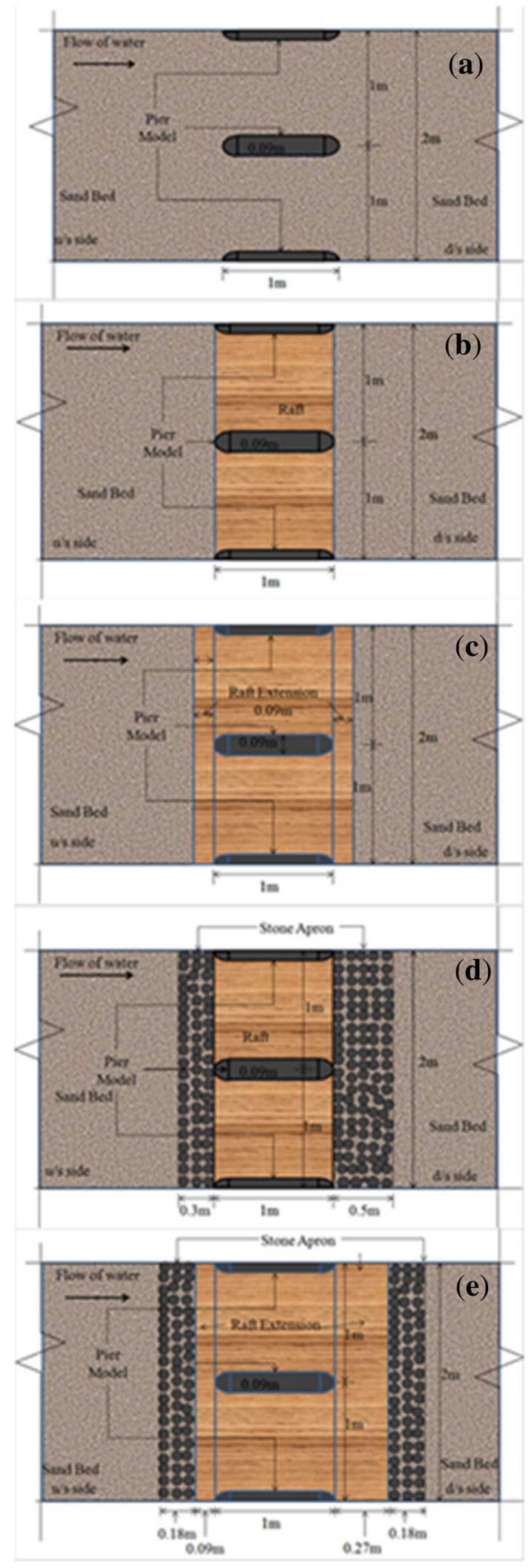

flow to be stabilised. In Case 2, experiments were conducted using the pier with raft foundation for identical flow discharges (figure $3 \mathrm{~b}$ ). The raft was made of marine
4Figure 3. Five following arrangements of pier resting on raft: (a) Simple pier, (b) Pier with raft foundations, (c) Raft extended to both $\mathrm{u} / \mathrm{s}$ and $\mathrm{d} / \mathrm{s}$ by a distance equal to the width of pier, (d) Raft with stone aprons up to a distance of $0.3 \mathrm{~m} \mathrm{u} / \mathrm{s}$ and $0.5 \mathrm{~m} \mathrm{~d} / \mathrm{s}$, and (e) Raft extended to u/s by a width of the pier and $\mathrm{d} / \mathrm{s}$ by three times of the pier width with stone aprons in both sides by a distance twice the pier width.

plywood as a rigid bed identical to raft foundation. The width of the raft is the same as the length of the pier. Cutoff walls were provided at the upstream and downstream end of pier along the entire length of the raft. Similarly, experiments were conducted for Cases 3-5 around the pier with raft foundation extending to upstream and downstream of the pier with or without aprons in the prescribed way with identical flow conditions (figure $3 \mathrm{c}-\mathrm{e}$ ). Here, for both Cases 4 and 5, the simple pier resting on raft foundation was provided with stone aprons on both sides of the pier. Table 3 shows the flow parameters such as discharges and corresponding average velocities, flow depths, maximum scour depths with Reynolds numbers and Froude numbers for all five cases.

\section{Experimental results and observations}

For Case 1 (figure 3a), the flow behaviour, scour pattern and behaviour of the horseshoe vortices were observed around the simple pier due to different flow discharges and water depths. It was observed that the maximum scour took place near the upstream nose of the pier, which threw light on the necessity for better scour protection measure in the upstream region of the pier. The maximum scour depth was obtained as $0.093 \mathrm{~m} \mathrm{[29]} \mathrm{for} \mathrm{the} \mathrm{highest} \mathrm{possible} \mathrm{discharge}$ of $0.21 \mathrm{~m}^{3} / \mathrm{s}$. A photograph of the scour hole for Case 1 is shown in figure 4 from the upstream side of the pier and a contour plot is provided in figure 5 for the scour hole. For Case 2 (figure $3 \mathrm{~b}$ ), the simple pier was provided with raft foundation with width of the raft equal to the length of the pier. The maximum depth of scour obtained for highest discharge was $0.077 \mathrm{~m}$. It was observed that the maximum scour depth occurred near the upstream nose of the pier, and the scour depth was reduced by almost 17\% than that of Case 1 due to the use of raft foundation [30]. This endorsed the fact that the use of raft foundation in Case 2 reduced the damaging strength of the horseshoe vortex and hence the reduction of scour formation. Shallow scour was observed at the downstream side, which extended to the wake region of horseshoe vortices at the downstream. Photographs of scour hole patterns for Case 2 are shown in figure 6a for upstream of raft foundation and in figure $6 \mathrm{~b}$ for downstream of the raft. The occurrence of scour on the upstream end of the pier led to the conclusion that there should be adequate scour protection measures at the upstream end. Therefore, the reduction in scour depth using raft 
Table 3. Flow parameters and scour depth for all cases.

\begin{tabular}{|c|c|c|c|c|c|c|}
\hline Case no. & $\begin{array}{c}\text { Discharge }\left(\mathrm{m}^{3} /\right. \\
\mathrm{s})\end{array}$ & Flow depth (m) & $\begin{array}{l}\text { Average velocity }(\mathrm{m} / \\
\mathrm{s})\end{array}$ & $\begin{array}{l}\text { Froude } \\
\text { number }\end{array}$ & $\begin{array}{l}\text { Reynolds } \\
\text { number }\end{array}$ & Maximum scour depth (m) \\
\hline \multirow[t]{7}{*}{1} & 0.03 & 0.11 & 0.14 & 0.13 & 15400 & 0.012 \\
\hline & 0.06 & 0.13 & 0.23 & 0.20 & 29900 & 0.0288 \\
\hline & 0.09 & 0.154 & 0.30 & 0.24 & 46200 & 0.041 \\
\hline & 0.12 & 0.163 & 0.37 & 0.29 & 60310 & 0.055 \\
\hline & 0.15 & 0.176 & 0.43 & 0.33 & 75680 & 0.067 \\
\hline & 0.18 & 0.19 & 0.47 & 0.34 & 89300 & 0.077 \\
\hline & 0.21 & 0.214 & 0.50 & 0.35 & 107000 & 0.093 \\
\hline \multirow[t]{7}{*}{2} & 0.03 & 0.11 & 0.14 & 0.13 & 15400 & 0.009 \\
\hline & 0.06 & 0.13 & 0.23 & 0.20 & 29900 & 0.023 \\
\hline & 0.09 & 0.154 & 0.30 & 0.24 & 46200 & 0.032 \\
\hline & 0.12 & 0.163 & 0.37 & 0.29 & 60310 & 0.04 \\
\hline & 0.15 & 0.176 & 0.43 & 0.33 & 75680 & 0.052 \\
\hline & 0.18 & 0.19 & 0.47 & 0.34 & 89300 & 0.065 \\
\hline & 0.21 & 0.214 & 0.50 & 0.35 & 107000 & 0.077 \\
\hline \multirow[t]{5}{*}{3} & 0.09 & 0.154 & 0.30 & 0.24 & 46200 & 0.015 \\
\hline & 0.12 & 0.163 & 0.37 & 0.29 & 60310 & 0.0169 \\
\hline & 0.15 & 0.176 & 0.43 & 0.33 & 75680 & 0.0194 \\
\hline & 0.18 & 0.19 & 0.47 & 0.34 & 89300 & 0.026 \\
\hline & 0.21 & 0.214 & 0.50 & 0.35 & 107000 & 0.03 \\
\hline \multirow[t]{7}{*}{4} & 0.03 & 0.11 & 0.14 & 0.13 & 15400 & 0 \\
\hline & 0.06 & 0.13 & 0.23 & 0.20 & 29900 & 0 \\
\hline & 0.09 & 0.154 & 0.30 & 0.24 & 46200 & 0.015 \\
\hline & 0.12 & 0.163 & 0.37 & 0.29 & 60310 & 0.02 \\
\hline & 0.15 & 0.176 & 0.43 & 0.33 & 75680 & 0.023 \\
\hline & 0.18 & 0.19 & 0.47 & 0.34 & 89300 & 0.027 \\
\hline & 0.21 & 0.214 & 0.50 & 0.35 & 107000 & 0.03 \\
\hline \multirow[t]{3}{*}{5} & 0.15 & 0.176 & 0.43 & 0.33 & 75680 & 0.004 \\
\hline & 0.18 & 0.19 & 0.47 & 0.34 & 89300 & 0.007 \\
\hline & 0.21 & 0.214 & 0.50 & 0.35 & 107000 & 0.01 \\
\hline
\end{tabular}

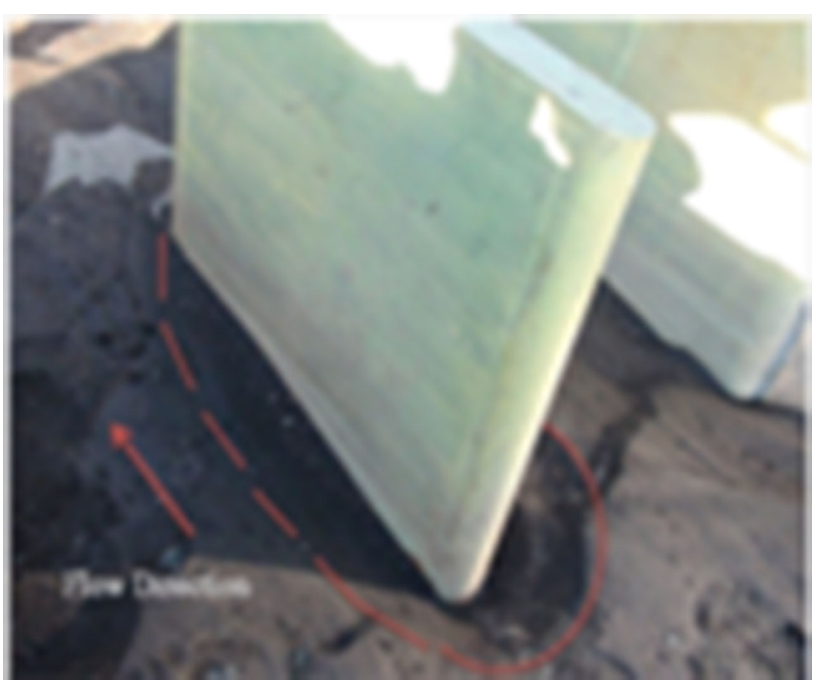

Figure 4. Scour pattern around simple bridge pier (Case 1).

foundation with extension is an important process to understand. A contour plot is also provided in figure 7 for scour hole obtained after using raft foundation.
Further, it will be interesting to know how the scour pattern would change if the raft foundation is extended to a distance of the width of the pier towards the upstream and downstream sides (Case 3, figure 3c). Hence, further experiments were carried out with an extension of the raft to the upstream side of the pier for five discharges. The extended raft was found to be very effective in reducing the damaging effect of the horseshoe vortices. The down-flow due to horseshoe vortex formation does not cause erosion of bed due to the presence of the rigid raft, thus reducing the scour depth considerably by $75 \%$. The scour depth was observed to be about $0.03 \mathrm{~m}$ for the highest discharge (Eldho et al [30] 2012), and the shallow scour was observed at the $d / s$ side. The scour patterns at $u / s$ and $d / s$ end are shown, respectively, in figure $8 \mathrm{a}$ and $\mathrm{b}$ using the extended raft by a distance equal to twice the width of the pier (Case 3). A contour plot is also provided in figure 9 for both $\mathrm{u} / \mathrm{s}$ and $\mathrm{d} / \mathrm{s}$ of the pier.

For Case 4 the pier was rested on the raft with stone apron up to $0.3 \mathrm{~m}$ in the $\mathrm{u} / \mathrm{s}$ side and $0.5 \mathrm{~m}$ in the $\mathrm{d} / \mathrm{s}$ side of the pier (figure 3d), which is typically used by the State of Maharashtra to construct bridges [25]. Experiments were conducted for seven different discharges. For the highest 


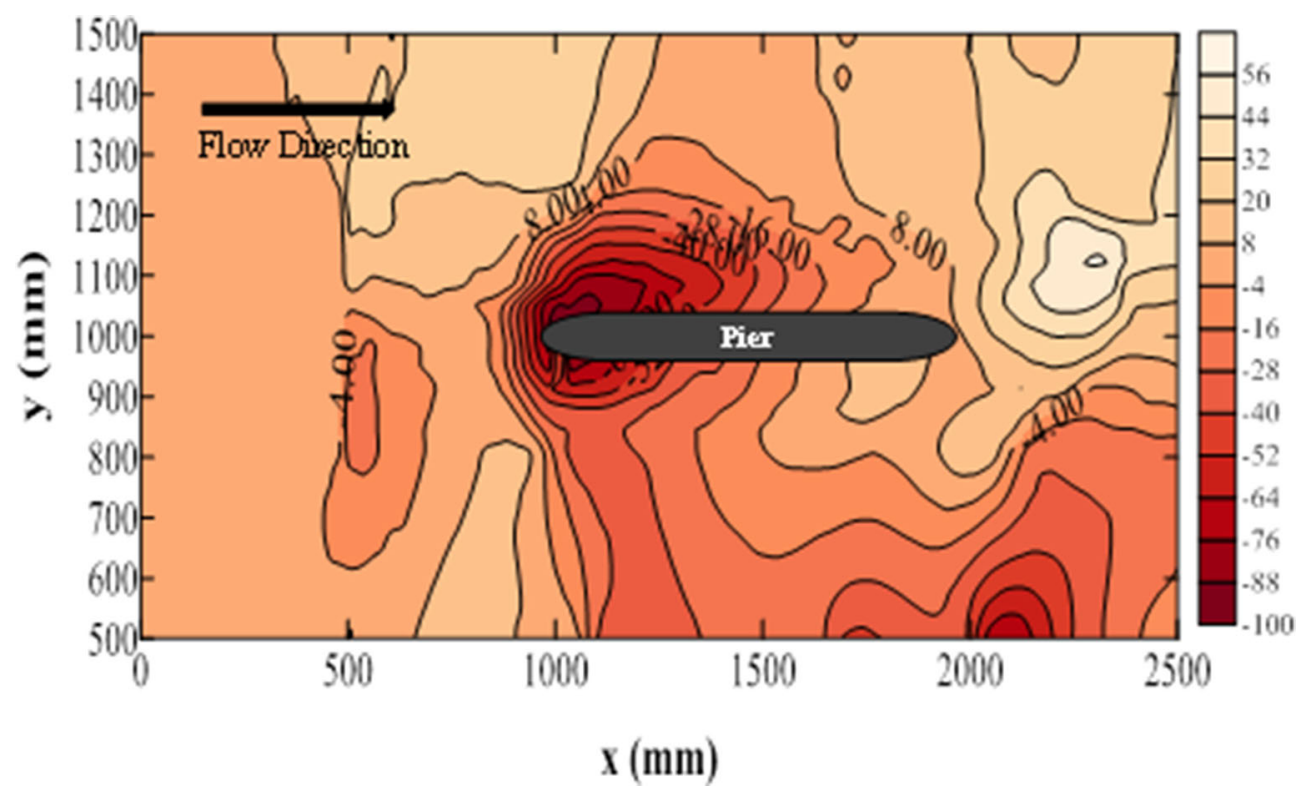

Figure 5. Scour contour for Case 1.
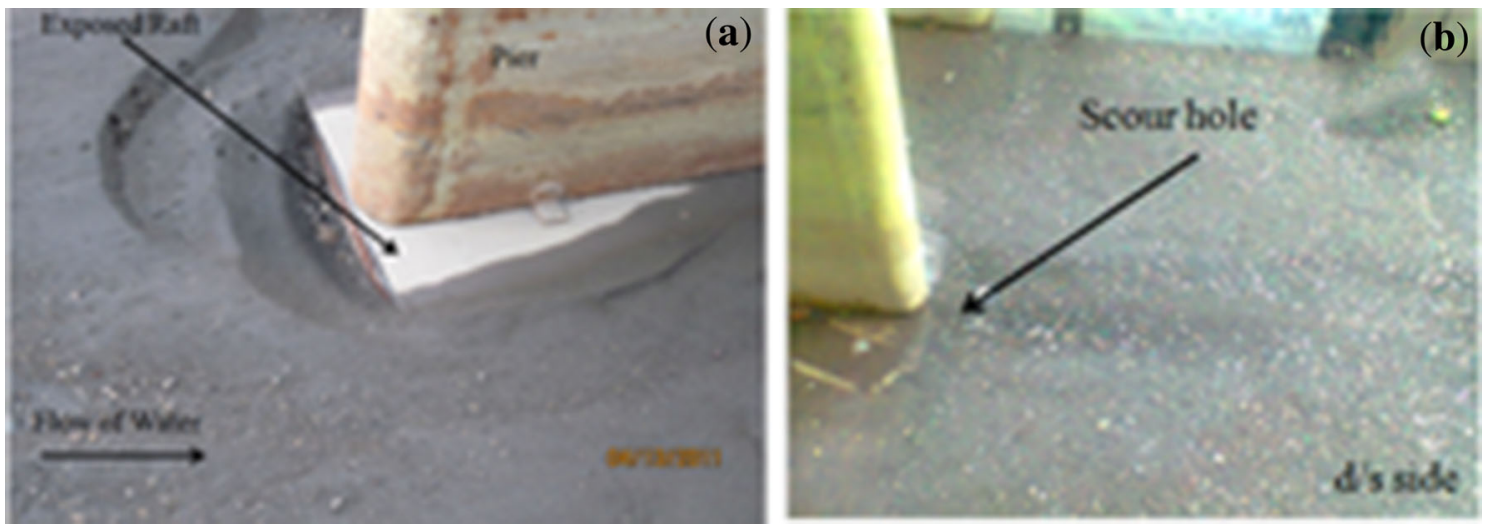

Figure 6. Scour pattern for Case 2: (a) raft at the upstream of the pier and (b) raft at the downstream.

discharge, minimal scour was observed at $\mathrm{u} / \mathrm{s}$ side (figure 10a), and shallow extended scour was observed at the $\mathrm{d} / \mathrm{s}$ side (figure 10b). It is observed that the system was saved from exposure to scour due to the stone apron. The contour plot is also shown in figure 11.

Finally, Case 5 (figure 3e) was studied by extending the raft towards the upstream by a distance equal to the width of the pier and downstream by thrice the width of pier along with laying of a stone apron of twice the width as that of the pier on both sides. For the previous cases, it was observed that for lower discharges, the scour depth was zero; hence, experiments were conducted for the highest three discharges in this case. The strength of the horseshoe vortices decreased considerably due to the presence of rigid raft extension with stone aprons. The formation of scour at $\mathrm{u} / \mathrm{s}$ of the pier is shown in figure $12 \mathrm{a}$ and that at the $\mathrm{d} / \mathrm{s}$ of the pier is shown in figure $12 \mathrm{~b}$. For the highest discharge, minimal scour was observed at $\mathrm{u} / \mathrm{s}$ side of the pier, but extended scour up to shallow depth was observed at the $\mathrm{d} / \mathrm{s}$ side of the pier. A contour plot for both sides is shown for better visualisation in figure 13 .

The observed values of scour depths $d_{m s}$ and corresponding seven flow discharges for all five cases (Cases 1$5)$ are shown in table 3 . The observed scour depth versus flow discharge per unit width $\left(D_{b}\right)$ for all five cases are presented in figure 14 with the theoretical curve plotted in the figure using Eq. (1) (IRC 78-2000 [15]). It is seen from the figure that the observed lines for the Cases 1 and 2 are above the theoretical curve for all seven discharges, indicating the increase of scour depth with the discharge, while for the Cases 3 and 4, the observed lines almost pass through the theoretical line for lower to medium discharges, 


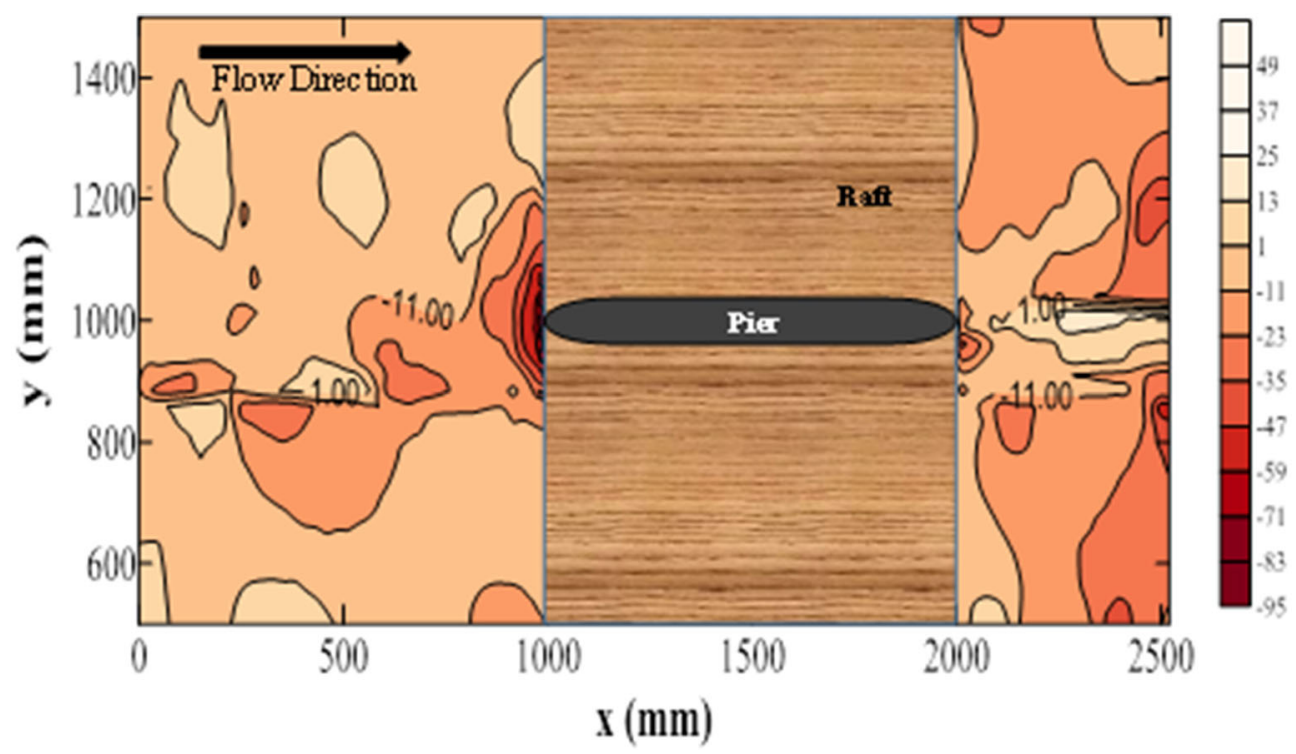

Figure 7. Scour contour for Case 2.
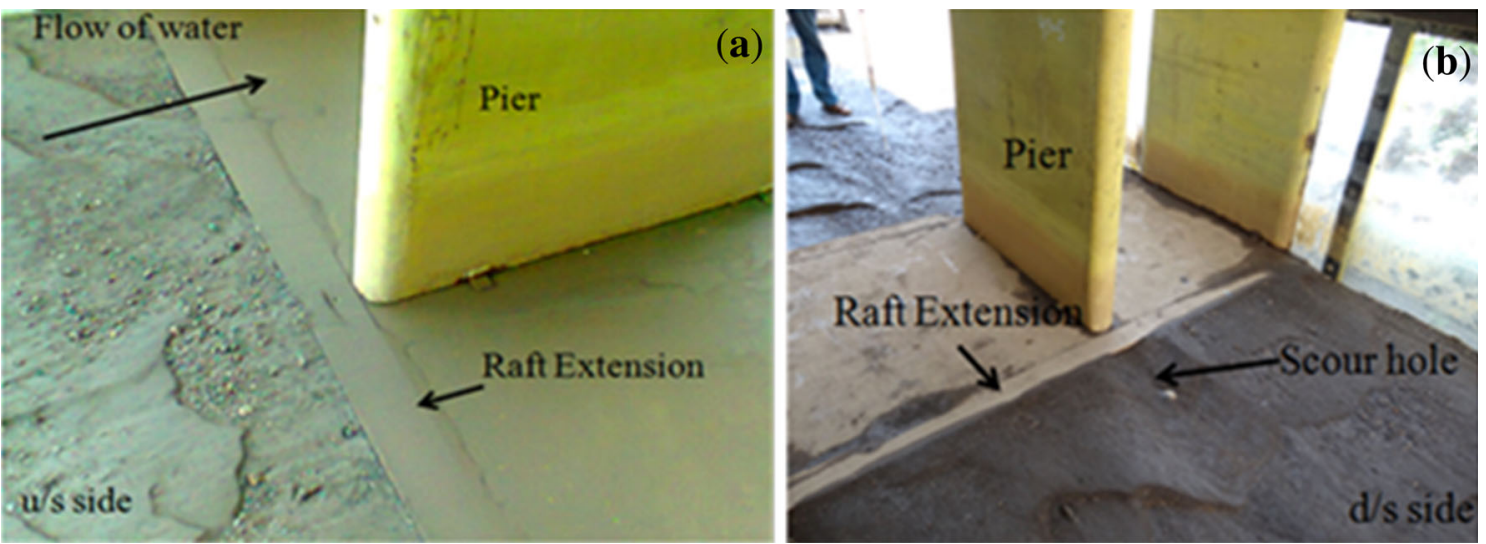

Figure 8. Scour pattern for Case 3: (a) raft at the upstream of the pier and (b) raft at the downstream.

and pass below the theoretical one, indicating lower scour depth. However, an interesting observation is that the obtained line for Case 5 is below the theoretical curve for higher discharges, indicating that the scour depth is very low. It may be mentioned here that for Cases 3 and 4, i.e., the pier resting on the raft with or without apron, there were no scours, almost zero depth, around the piers for lower discharges $0.03-0.06 \mathrm{~m}^{3} / \mathrm{s}$, and for Case 5 , no scour occurred for discharges $0.03-0.12 \mathrm{~m}^{3} / \mathrm{s}$; hence, the observed lines are not drawn in the figure. As the scour hole was at a distance of five times the width of the pier for Case 5 , the bridge foundation could be considered as the safest, without any risk. This arrangement could be considered as the best to protect the pier from the damages due to scours.

\section{Discussion}

As discussed earlier, the State of Maharashtra in India has a practice of providing raft foundation with cut-off and stone aprons for a minimum distance of $0.3 \mathrm{~m} \mathrm{u} / \mathrm{s}$ and $0.5 \mathrm{~m} \mathrm{~d} / \mathrm{s}$ of the pier for scour protection measure [25]. In order to understand the efficacy of stone aprons to reduce scours even around the raft foundation, the stone aprons were laid down for a distance of $0.3 \mathrm{~m} \mathrm{u} / \mathrm{s}$ and $0.5 \mathrm{~m} \mathrm{~d} / \mathrm{s}$ of the pier, (Case 4) The experimental observations indicated that by providing stone aprons upstream and downstream, the scour reduced by almost $68 \%$ in comparison with the condition in which the pier was not provided with raft foundation. The stone aprons prevented the raft foundation from being 


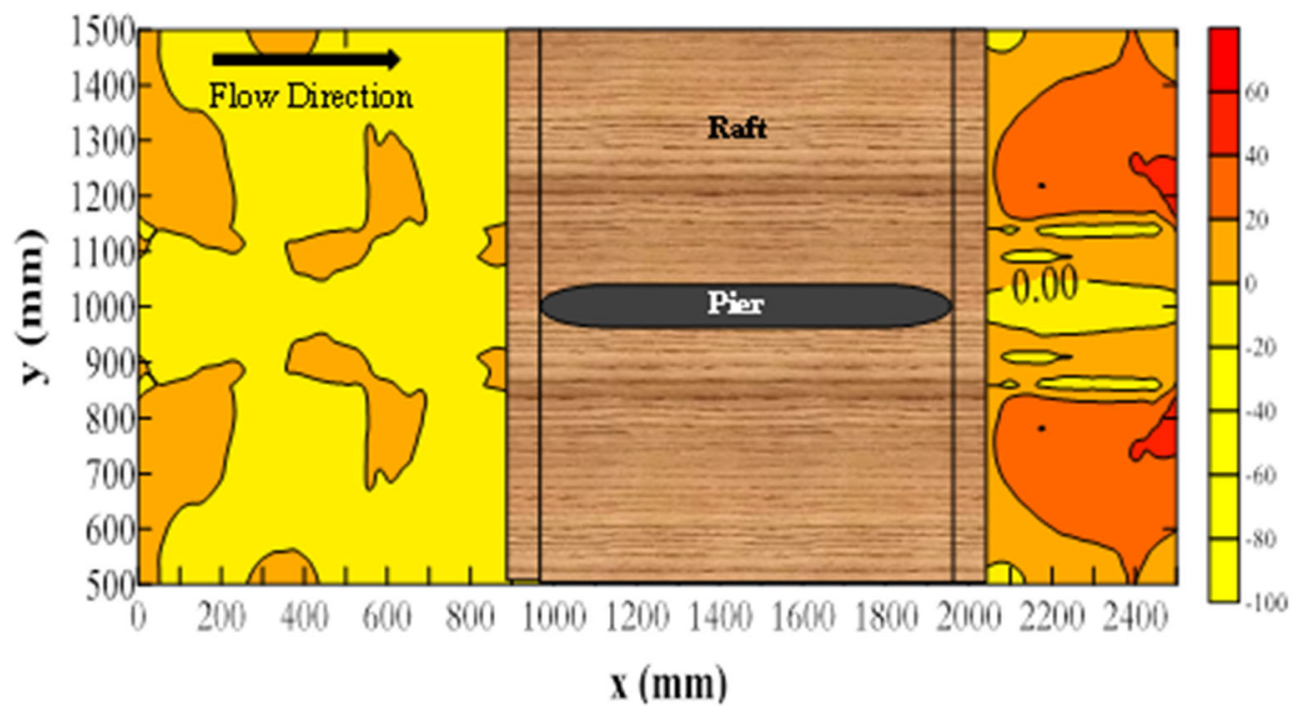

Figure 9. Scour contour for Case 3.
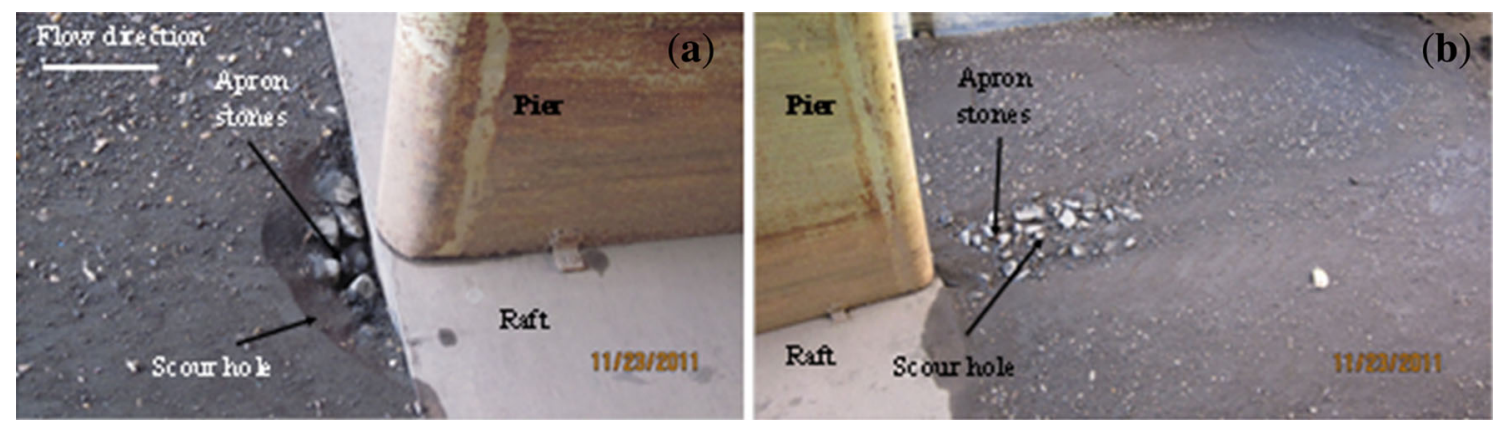

Figure 10. Scour pattern for Case 4: (a) raft with apron at the upstream of the pier and (b) raft with apron at the downstream.

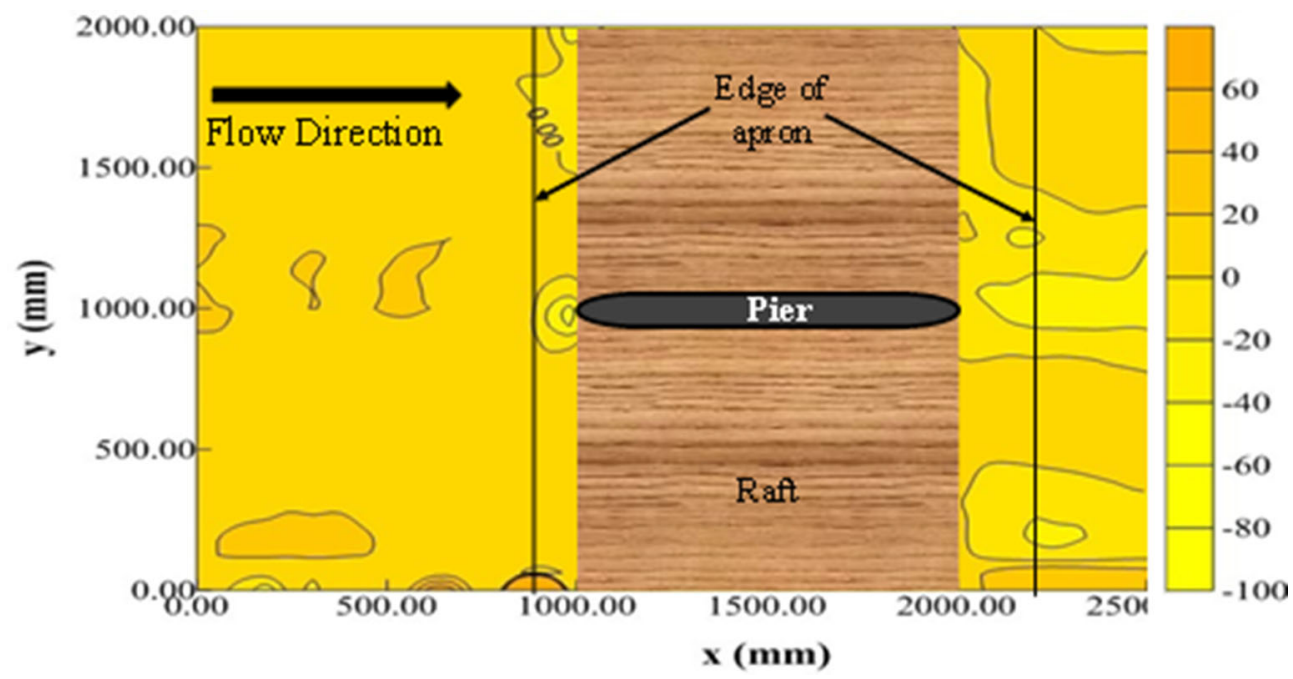

Figure 11. Scour contour for Case 4. 

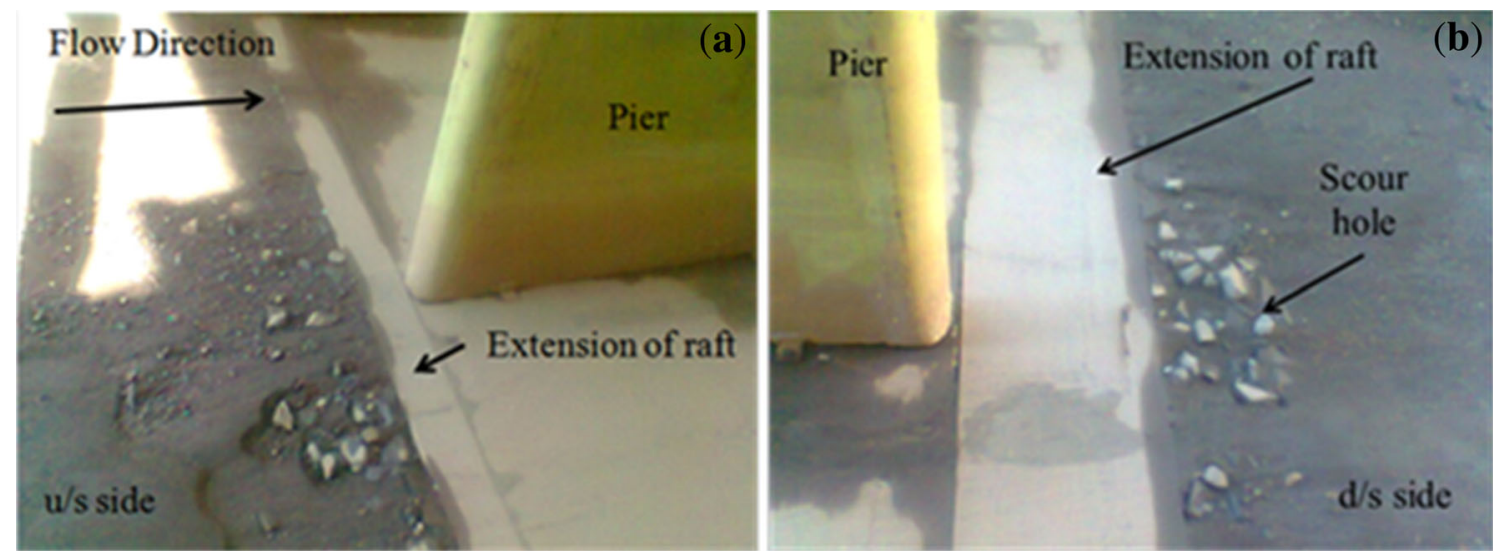

Figure 12. Scour pattern for Case 5: (a) extended raft with apron at the upstream of the pier and (b) extended raft with apron at the downstream.

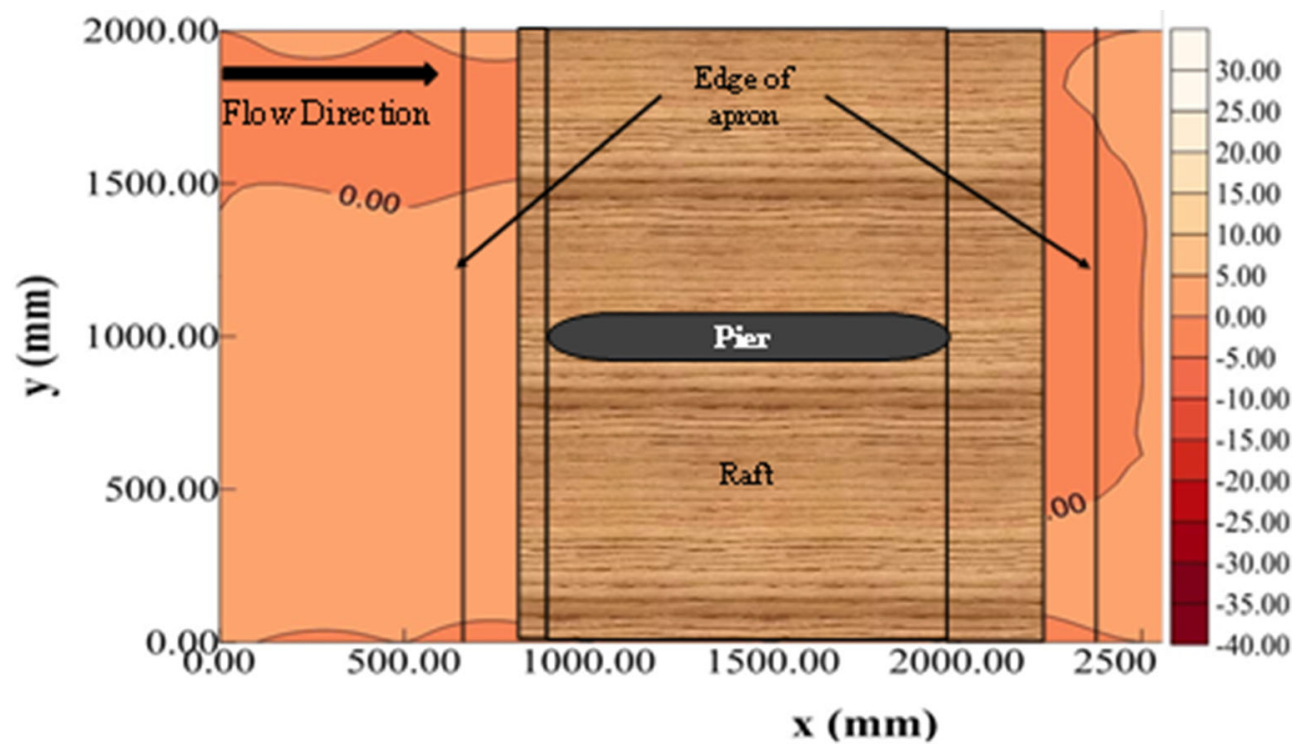

Figure 13. Scour contour for Case 5.

exposed and provided adequate safety to the pier [32]. Stone apron materials were modelled as per IRC norms $[15,16]$ and scaling considerations given by Eldho et al [31]. The strength of the horseshoe vortices reduced to a certain extent due to the presence of the stone aprons, preventing the raft from being exposed. Sand dislodged from the upstream end of the pier, thereby exposing the stone aprons. A shallow scour hole with more areal extent was observed at the downstream side of the pier, which justifies the provision of the wider stone apron on the downstream side. Though the extension of the raft is very effective, it is less economical, as in the field, the RCC raft needs to be extended throughout the length of the bridge. The cost of extension of raft will be proportional to the cost of raft itself. The provision of a raft with aprons is a more economical option, but stone aprons could be easily displaced, if not monitored and replaced periodically.
Considering all different cases as discussed earlier, it is noticed that there is still a shallow scour at the downstream side of the pier. Hence, a combination of the extension of raft and aprons was considered (Case 5). The raft was extended to $\mathrm{u} / \mathrm{s}$ by a width of the pier $(0.09 \mathrm{~m})$ and $\mathrm{d} / \mathrm{s}$ by three times the width of the pier $(0.27 \mathrm{~m})$ with stone aprons at both sides by a distance twice the pier width. Therefore, the scour protection towards $\mathrm{u} / \mathrm{s}$ side was provided for a distance of $0.27 \mathrm{~m}$, which was three times the width of the pier. The scour protection towards the $d / s$ side was for a distance of $0.45 \mathrm{~m}$, which was five times the width of the pier. The protection was provided for the entire width of the raft. Scours were minimal at the upstream and downstream end. The scour depth obtained was much less than the mean scour depth (IRC 78-2000 [15]). This system may be considered to be the safest, as the shallow scour hole was at a considerable distance from the pier and was compensated 


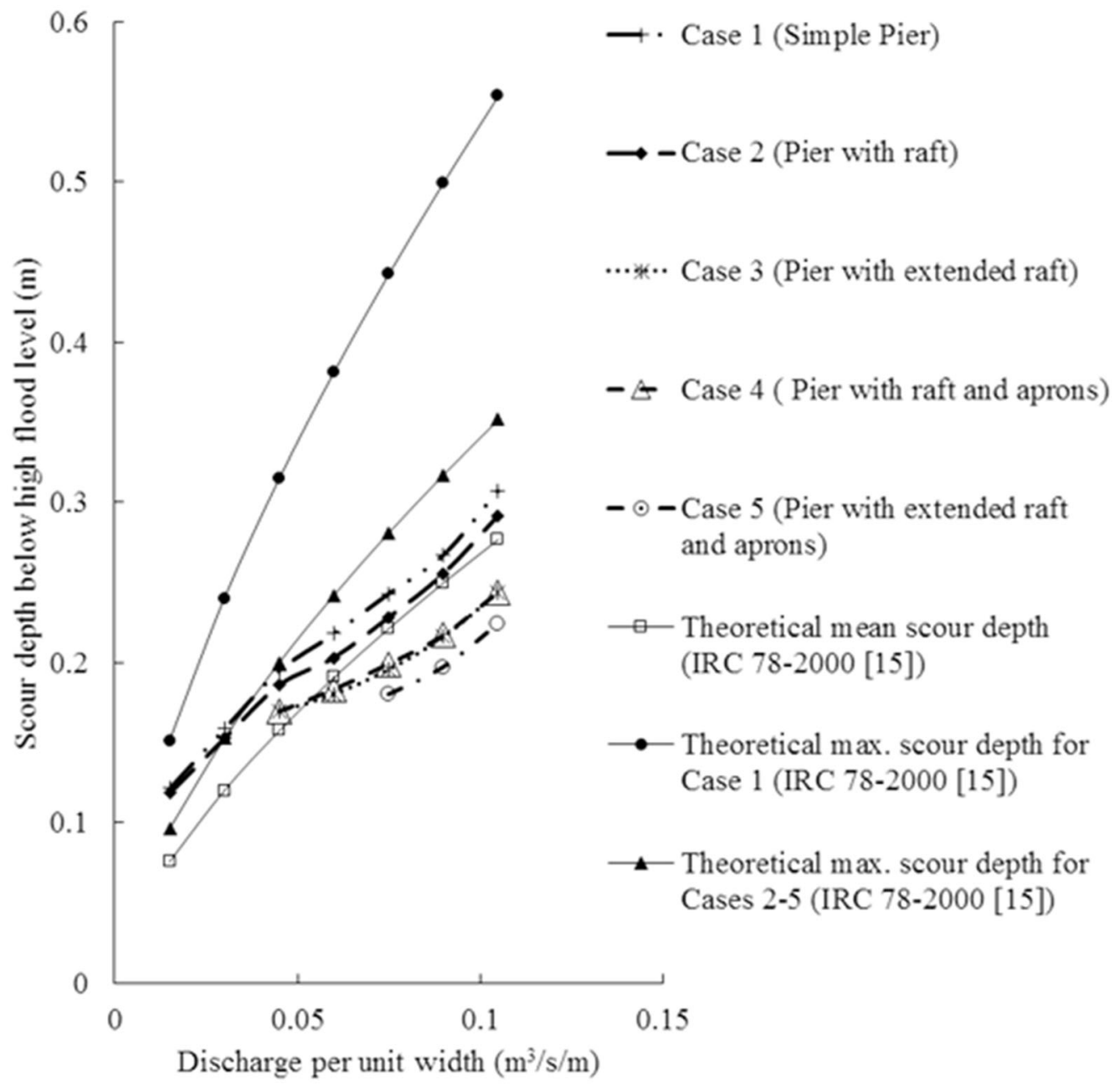

Figure 14. Variation of scour depth with discharge per unit width for all the cases.

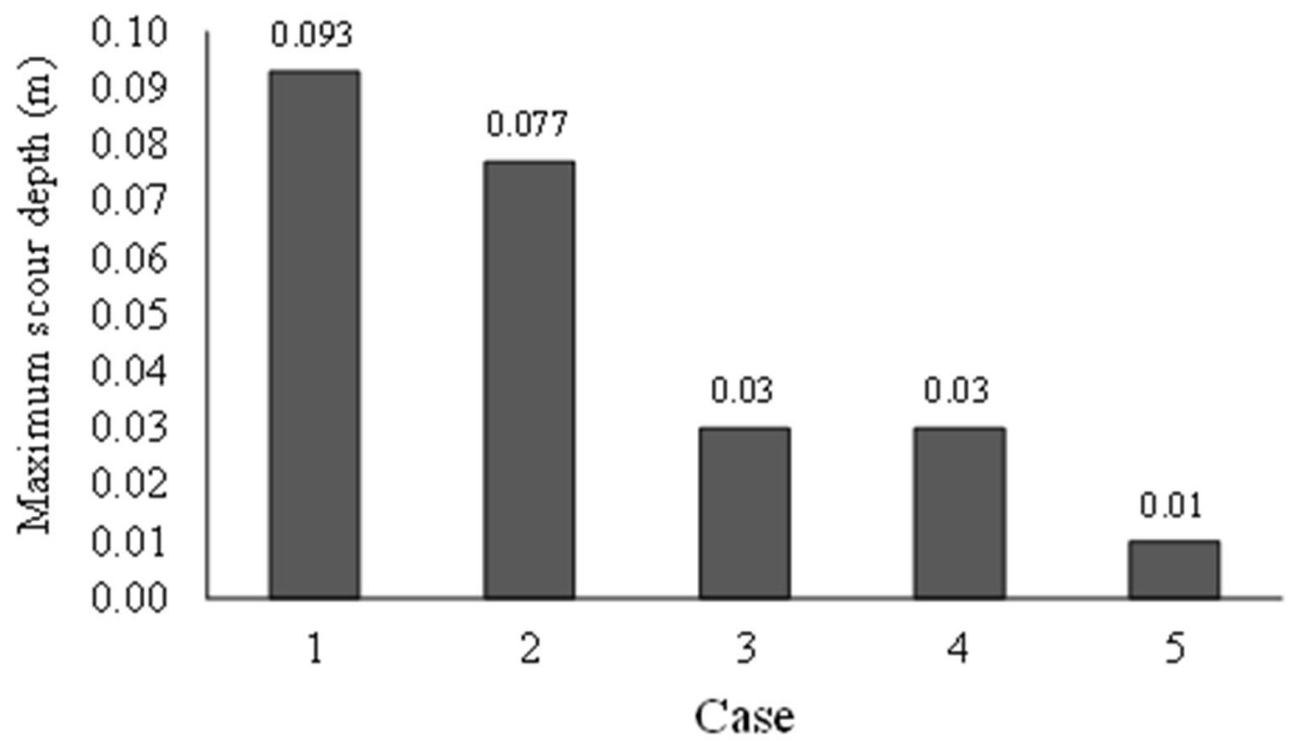

Figure 15. Histogram plots for comparison of scour depths for various cases. 
by stone aprons. Provision of an extended raft with stone apron seemed to be an ideal protection system against scours. The flow parameters and scour depth for the different combinations (Cases) studied are summarised in table 3. Figure 15 shows the histogram plots for comparison of scour depths for various cases considered in the study. The results, which are given in table 3 and figure 15, indicated the effectiveness of raft foundation and its variations as a scour protection measure around bridge piers. As can be seen, Case 5 gives the least-depth scour and the most effective scour protection measure. The procedure followed in Maharashtra, as in Case 4, seems to be more effective scour protection measure while considering the cost of construction, but the maintenance cost would be more.

The experimental observations indicated that the strength of the horseshoe vortex reduced considerably due to the presence of rigid raft extension and stone aprons for Case 5, which significantly reduces the scour depth. It is observed that the arrangement can be made as the best way to protect the pier from damages due to heavy scours, though it may be slightly costlier.

Usually, the practice is to keep the raft top at $30 \mathrm{~cm}$ below the lowest bed level. The river is expected to adjust itself with the rigid raft provided in due course of time. The provision of the raft foundation and the stone apron is done at the time of the construction of the bridge. Therefore, no additional burden falls upon the marine life, environment and flow of the river, other than those caused by the construction of the bridge. Moreover, this system is more suitable for small and medium rivers and the impact on the environment is also observed to be considerably less [25].

Scours would be an issue whenever an obstruction is present in an alluvial river, at the sand bed level. Raft foundation is used for bridges in river beds where hard rock stratum is not available to a reasonable depth whereas thick sandy beds are available to a reasonable depth. The raft foundation acts as an integrated system of foundation and scour protection measure. Generally, pile foundations are employed when the soil layer is weak at the surface and hard stratum is available at a reasonable depth. However, we need to give separate scour protection measures in the case of pile foundation. Raft foundation is preferred for small to medium size rivers whereas pile foundations are preferred for very large rivers.

As shown in the present study, the most effective scour protection measure is the raft extended to $\mathrm{u} / \mathrm{s}$ side by a distance equal to the width of the pier and to the $\mathrm{d} / \mathrm{s}$ side by a distance equal to three times the width of the pier. Stone aprons can be provided at $\mathrm{u} / \mathrm{s}$ and $\mathrm{d} / \mathrm{s}$ side of the extended raft for a width equal to twice the width of the pier. The results obtained from this model study may be adopted for future bridge designs using raft foundation.

\section{Conclusions}

For most of the bridge failures, the major cause is due to scouring effects and hence effective scour protection measures are required. In this study, the effectiveness of combination of raft foundation using aprons as a scour protection measure against bridge pier scour is investigated through physical model studies. Following are the major conclusions from the study.

- When the rigid floor is provided in the form of raft foundation for the bridge, the scour is only due to the horseshoe vortex formation on $\mathrm{u} / \mathrm{s}$ side and wake/ separation on the $\mathrm{d} / \mathrm{s}$ side of the pier.

- A small extension of rigid raft both on $u / s$ and $d / s$ reduces the horseshoe vortex effect and scour.

- Provisions of stone aprons on $\mathrm{u} / \mathrm{s}$ and $\mathrm{d} / \mathrm{s}$ of rigid raft are found to be effective in reducing immediate local scours beyond the rigid raft.

- The practice used in Maharashtra, India, of providing a concrete raft with $\mathrm{u} / \mathrm{s}$ and $\mathrm{d} / \mathrm{s}$ cut-off and flexible stone aprons at $\mathrm{u} / \mathrm{s}$ and $\mathrm{d} / \mathrm{s}$ has been found to be a very effective scour protection measure for bridges where shallow foundation is economical.

- A provision of an extended raft with stone apron seems to be an ideal protection system against scours. Extending the raft along the entire span may result in the increase in the cost of construction in comparison with the provision of stone aprons. However, this increase in cost will be compensated by the maintenance cost of the bridge because an extension of the concrete raft would be more stable than the stone aprons.

\section{Acknowledgements}

Authors are thankful to the Ministry of Road Transport and Highways (MORTH) for sponsoring the project titled "Hydraulic Model Investigations for Design of Raft Foundations for Bridges (B-40)" and the Director General, Chief Engineer, Superintending Engineer and Executive Engineer for co-coordinating the project. We express our sincere gratitude to Shri P L Bongirwar, Former Secretary, Maharashtra PWD, and Late Prof. U C Kothyari, Indian Institute of Technology Roorkee, for all the suggestions, help and support provided during the initial stages of this study. We are also thankful to the former and present engineers of Maharashtra PWD (Shri R.R Chonkar, Shri J. T. Nashikkar, Smt. Sanjivani Nigade Saha and others) and the staff of Hydraulics laboratory, IIT Bombay, for their untiring support and help rendered during model preparation and testing.

Funding Funding was provided by Ministry of Road Transport and Highways (MORTH), New Delhi (Grant No. 09MORTH001). 


\section{References}

[1] Chiew Y and Melville B M 1987 Local scour around bridge piers. J. Hydraul. Res. 25(1): 15-26

[2] Kothyari U, Garde R J and RangaRaju K G 1992 Temporal variation of scour around circular bridge piers. J. Hydraul. Eng. ASCE 118(8): 1091-1106

[3] Melville B W and Chiew Y M 1999 Time scale for local scour at bridge piers. J. Hydraul. Eng. ASCE 125(1): 59-65

[4] Clopper P E, Lagasse P F and Zevenbergen L W 2007 Bridge pier scour countermeasures. In: Proceedings of World Environmental and Water Resources Congress 2007, ASCE, Reston, VA, pp. 1-13

[5] Korkut R, Martinez E J, Morales R, Ettema R and Barkdoll B 2007 Geobag performance as scour countermeasure for bridge abutments. J. Hydraul. Eng. ASCE 133(4): 431-439

[6] Tabarestani M K and Zarrati A R 2013 Design of stable riprap around aligned and skewed rectangular bridge piers. J. Hydraul. Eng. ASCE 139(8): 911-916

[7] Yoon T H and Kim D H 2001 Bridge pier scour protection by sack gabions. In: Bridging the Gap: Meeting the World's Water and Environmental Resources Challenges, pp. 1-8

[8] Gris R B 2010 Sheath for reducing local scour in bridge piers. In: Proceedings of International Conference on Scour and Erosion 2010 (ICSE-5), pp. 987-996

[9] Heidarpour M, Afzalimehr H and Izadinia E 2010 Reduction of local scour around bridge pier groups using collars. Int. J. Sedim. Res. 25(4): 411-422

[10] Izadinia E and Heidarpour M 2012 Simultaneous use of cable and collar to prevent local scouring around bridge pier. Int. J. Sedim. Res. 27(3): 394-401

[11] Masjedi A, Shafael B M and Esfandi A 2010 Experimental study on local scour around single oblong pier fitted with a collar in a 180 degree flume bend. Int. J. Sedim. Res. 25(3): 304-312

[12] Tang H W, Ding B, Chiew Y M and Fang S L 2009 Protection of bridge piers against scouring with tetrahedral frames. Int. J. Sedim. Res. 24(4): 385-399

[13] Wang C Y, Cheng J H, Shih H P and Chang J W 2011 Ring columns as pier scour countermeasures. Int. J. Sedim. Res. 26(3): 353-363

[14] Gaudio R, Tafarojnoruz A and Calomino F 2012 Combined flow-altering countermeasures against bridge pier scour. $J$. Hydraul. Res. 50(1): 35-43

[15] IRC 78-2000 Standard specifications and code of practice for road bridges. New Delhi: The Indian Roads Congress

[16] IRC 89-1997 Guidelines for design and construction of river training and control works for road bridges. New Delhi: The Indian Roads Congress

[17] Mashahir M, Zarrati A and Mokallaf E 2010 Application of riprap and collar to prevent scouring around rectangular bridge piers. J. Hydraul. Eng. ASCE 136(3): 183-187
[18] Zarrati A R, Chamani M R, Shafaie A and Latifi M 2010 Scour countermeasures for cylindrical piers using riprap and combination of collar and riprap. Int. J. Sedim. Res. 25(3): 313-322

[19] Chiew Y 1992 Scour protection at bridge piers. J. Hydraul. Eng. ASCE 118(9): 1260-1269

[20] Chiew Y 1995 Mechanics of riprap failure at bridge piers. $J$. Hydraul. Eng. ASCE 121(9): 635-643

[21] Chiew Y M and Lim F H 2000 Failure behavior of riprap layer at bridge piers under live-bed conditions. J. Hydraul. Eng. ASCE 126(1): 43-55

[22] Dey S and Sen D 2005 Determination of scour depth (for general bed, within channel contractions and at bridge piers) in boulder bed rivers under high stream velocities. Research and Development Scheme No. B-33, Final Report to Ministry of Road Transport and Highways, Standards and Research (Bridges), Government of India, New Delhi

[23] Kothyari U C 2007 Indian practice on estimation of scour around bridge piers—a comment. Sadhana 32(pt3): 187-197

[24] Ugalmugle A and Namjoshi A G 2004 Construction of raft foundation in deep sandy beds for major bridges across perennial rivers. J. Indian Roads Cong. (Paper No. 506): 422-461

[25] Borge V B and Jangde K S 2005 Innovative bridge foundations in weak soils-experiments and practice in Maharashtra. J. Indian Roads Cong. (Paper No. 518): 455-484

[26] Subramanya K 2012 Flow in open channels. New Delhi: Tata McGraw-Hill Education

[27] Streeter V L and Wylie E 1975 Fluid mechanics. New Delhi: Tata McGraw-Hill Education

[28] Head K 2006 Manual of soil laboratory testing. Dunbeath: Whittles Publishing

[29] Eldho T I, Viswanadham B V S and Vijayasree B A 2010 Physical model study of scouring effects on pier foundation of bridges. In: Proceedings of Indian Geotechnical Conference 2010, GEOtrendz, IIT Bombay, India, pp. 973-976

[30] Eldho T I, Viswanadham B V S and Vijayasree B A 2012 Physical model studies on extended raft foundation of bridges as a scour protection measure. In: Proceedings of the National Conference on Hydraulics, Water Resources, Coastal and Environmental Engineering (HYDRO-2012), IIT Bombay, India

[31] Eldho T I, Viswanadham B V S, Vijayasree B A and Siva Naga Venkat N 2011 Physical model study of scouring effects on rafty foundation of bridge piers. In: Proceedings of Indian Geotechnical Conference 2011, Kochi, India, pp. 907-910

[32] Vijayasree B A, Eldho T I and Viswanadham B V S 2013 Physical model studies on bridge piers with raft foundation and aprons as a scour protection measure. In: Proceedings of HYDRO 2013 International, IIT Madras, India 